\title{
INFLUENCE OF HARVEST TIME OF WINTER WHEAT VARIETIES TO THE GRAIN YIELDS IN THE CONDITIONS OF THE SOUTHERN REGION
}

\author{
Ishonkulova Gavkhar Norkulovna \\ Assistant Teacher of Karshi Engineering-Economics Institute, \\ Department "The Technology of Storage and Primary Processing of Agricultural Products", \\ Karshi city, Uzbekistan,
}

Article DOI: https://doi.org/10.36713/epra6808

DOI No: 10.36713/epra6808

\begin{abstract}
This article describes the differences of winter wheat "Selyanka", "Jayhun", "Krasnadarskaya-99" and "Turkiston" in the conditions of ancient irrigated, grazing light gray and barren soils of Kashkadarya region. the Turkestan variety was observed on May 14, May 22, June 8, respectively, while the phase was observed on May 21 and the full ripening phase on June 7; Krasnadarskaya-99 variety matured on May 16, May 24, June 10 and Jayhun variety on May 18, May 26, June 12, or the Turkestan variety growing season was 1 day, Krasnadarskaya-99 variety ripened for 3 days and Jayhun variety ripened 5 days later than Selekta. Turkestan and Krasnadarskaya-99 varieties of winter wheat and Selyanka and Jayhun varieties of winter wheat in the conditions of high irrigated soils, when the harvest period reaches the stage of full ripening on June 5-7 in the conditions of light gray soils grazing in order to obtain high and quality harvests of winter wheat. June 7-12 to reap the full maturity stage, when the impact of information.

KEYWORDS - previously irrigated, grazing light gray soil, barren soil, winter wheat varieties "Selyanka”, “Jayhun”, “Krasnadarskaya-99" and "Turkiston", harvest dates, grain harvest of winter wheat.
\end{abstract}

\section{INTRODUCTION}

Nowadays, the steady growth of the world's population is important in meeting the growing needs of humankind in food and agricultural products, as well as in increasing the yield and quality of cereals, including winter wheat. It is also home to more than 200 million people in more than 100 countries around the world. Wheat is planted on more than a hectare and 729.0 million tons of grain is grown. Of this, the share of winter soft wheat is $90-95$ percent. At the same time, in many countries there is a growing interest in the timing of the harvest of winter wheat in order to obtain high quality crops. According to a report by the United Nations (UN) and the Food and Agriculture Organization (FAO) in October 2017, global grain production was high in 2017, at 2.612 billion tonnes, up from 6.8 million tonnes in 2016. tons. The huge reforms implemented in Uzbekistan over the past short period of independence have made it possible to radically diversify agriculture and fully provide the population with ecologically clean food products and export them. One of the important tasks in the Action Strategy for further development of the Republic of Uzbekistan for 2017-2021 is ".3.3. Application of intensive methods in agricultural production, first of all, modern agro-technologies that save water and resources", [1,2,3].

Taking into account these tasks, to conduct scientific research on the maintenance of soil fertility and land reclamation, as well as the development of optimal timing of sowing, irrigation regimes, mineral fertilizer standards, harvesting timing of winter wheat in different soil climates. is up to date.

Lukyanenko P.P. in gaining high and quality grain harvest from winter wheat. Krasnodar Agricultural Research Institute, Saratov Agricultural Research Institute 
"Yuga-Vostoka" and Serbian Novi Sad Field Vegetable Research Institute (Russian Federation), International IKARDA, SIMMIT leading research centers Autumn wheat agrotechnologies from foreign scientists: Sayko V.F, Prutskov F.M, Osipov I.P, Nikolaev E.V, Wahdan A.A, Abd El Aty, Ibrahim M., Dr. Zoltán Adamis, János Kátai1 and studied by others.

Research on the characteristics of the variety, adaptation to different soil and climatic conditions, the development of agrotechnologies for obtaining high and high-quality grain crops in the cultivation of winter wheat on irrigated lands of the Republic Khalikov B., Siddikov R., Amanov A., Khalilov N., Atabaeva H., Ibragimov N., Amanov O., Bakhramov A., Isaev S., Abdurahmanov S., Hoshimov I and other scientists conducted scientific research $[4,5,6,7,8,9]$.

The shelf life of grain is the period of complete shelf life of all quality indicators in the baking of edible bread. The shelf life of seed grains is slightly shorter than the shelf life of grains used for consumption. Storage of seed grains is divided into two shelf life. The first shelf life is the biological shelf life, which is called the final shelf life of the grain, or the period during which it is able to retain its viability, even if only one. The second is the shelf life, which is important for the farm, depending on the type of grain, the period of germination that meets the requirements of state standards. The technological shelf life of grains is also taken into account. This shelf life is the period during which the grain mass fully meets the conditioning requirement according to the state standard, depending on the area of use (technical purposes for feed for consumption), [10].

If the varietal purity of the seeds is $99.5 \%$, they are divided into the second and third categories if the first is 98 and $95 \%$. Variety purity of elite seeds should be $99.7 \%$. The quality indicators of seeds of winter wheat cereals are as follows: the main seed quantity (purity), contamination and germination. Depending on these parameters of the grain, the seeds are divided into different classes, [15,16,17,18,19,20].

The study of winter wheat varieties Selyanka, Jayhun, Krasnadarskaya-99 and Turkiston on the timing of harvest, as well as the effect on the quality of grain has not been studied in the conditions of lightly irrigated pastures and light gray and barren soils of Kashkadarya region.

\section{The Aim of the study}

To determine and recommend recommendations for the production of high-quality grain of winter wheat from Selekta, Jayhun, Krasnadarskaya-99 and Turkestan varieties in the conditions of ancient irrigated pastures and light gray and barren soils of Kashkadarya region in the southern region of Uzbekistan.

Object of research: ancient irrigated grazing light gray and barren soils, winter wheat varieties
"Selyanka", “Jayhun", “Krasnadarskaya-99" and "Turkiston".

As a subject of research growth and development and yield of winter wheat, as well as the technological quality of the grain.

\section{THEORY}

Conducting laboratory and field experiments, phenological observations and biometric measurements, soil and plant sampling and their analysis in the research work "Methods of field opioids with cereal cultures", "Methods of state sortoispytaniya selskokhozyaystvennyeken kultur", "Methodology of agricultural culture", "Methodology of agricultural culture" «Methods of biochemical research of plants», «Methods of conducting field experiments» and «Methods of agrochemical, agrophysical and microbiological research in polyvnykh khlopkovy rayonax carried out on the basis of guidelines, manuals, $[11,12,13,14]$.

Once the grain crop is ripe, it is definitely time to start harvesting them. However, the yield is lower than the identified biological yield structure and approbation data. This is due to the fact that the harvest was not carried out on time, the work was not organized properly. Failure to take into account the economic characteristics of varieties of winter wheat, the lack of placement of varieties depending on the characteristics of the region at the time of sowing affects the yield and technological quality of grain.

\section{STATEMENT OF THE PROBLEM}

Kashkadarya region is located in the south-west of Uzbekistan, its northern and western sides are surrounded by mountains. Therefore, the Karshi steppe (Bahoristan, Mubarek, Mirishkor, Kasbi, Kasan, Karshi and Nishan districts) located in the region receives cold air from the north and hot air from the west from Karakum. This situation in turn creates a sharp continental climate. Summers are hot, long and dry, winters are short and cold, and springs are relatively humid. The weather changes with the wind blowing from the steppe to the mountains. Positive temperature is $+49000-5000$ degrees, effective temperature is + 2519-2980 degrees, cold days are 213233 days.

The first autumn frost occurs from October 14 to November 2, and the last spring frost occurs on March 1625 . Constant temperature above +10 degrees occurs $14-19$ times in a typical gray soil zone.

In the zone of typical and light gray soils it is +25.3 degrees. The average daily temperature in July is +28 degrees in the middle reaches of Kashkadarya and +31.6 degrees in the desert zone. The maximum temperature in this zone reaches 47-50 degrees. During 
this period, the relative humidity decreases to $22 \%$, and during the day there is a hot wind due to drought.

Precipitation is very low, $40-140 \mathrm{~mm}$ during the growing season, 104-394 $\mathrm{mm}$ in autumn, winter and spring. Moisture evaporation is $1110-1580 \mathrm{~mm}$ during the growing season and 394-402 $\mathrm{mm}$ during the off-season.

In the 2011 experiment, the average daily air temperature rose from 5-80C in January and February to 350 S in July, then dropped to 100S in December. In 2012, it rose sharply from $100 \mathrm{~S}$ in January to $350 \mathrm{~S}$ in May, and to $380 \mathrm{~S}$ in July and August.

Field experiments were carried out on the experimental plot of the Kashkadarya Research Institute of Cereal Breeding and Seed Production in the conditions of ancient irrigated pastures of light gray and barren soils of Kashkadarya region. The mechanical composition of the soil of the experimental field is sandy, the groundwater depth is $2.5-3.0 \mathrm{~m}$, the area of winter wheat varieties "Selyanka", "Jayhun", "Krasnadarskaya-99" and "Turkiston" is $360 \mathrm{~m} 2$. (row length $64.3 \mathrm{~m}$, ie 8 rows x 0.7 $=5.6 \mathrm{~m}$ ), of which $180 \mathrm{~m} 2$ are taken into account, 4 rows, all options are schematically placed in one tier and determine the optimal timing of ripening of winter wheat grain, harvest - Science-based technology for the timely and correct organization of harvesting The purpose of the creation of the INI.

Field and laboratory experiments were carried out on the basis of the methodological manual of the AllRussian Scientific Research Institute of Botany. Phenological observations and biometric analyzes were carried out in accordance with the methodological guidelines of the State Commission for Variety Testing of Agricultural Crops.

In the conditions of ancient irrigated grazing light gray soils, the content of humus in the tillage (0-30 $\mathrm{cm}$ ) layer of the soil is $1.26 \%$, total nitrogen $2.13 \%$, phosphorus $2.11 \%$, potassium $2.41 \%$, their mobile forms are 14 , respectively. 6; 25.3; At $223 \mathrm{mg} / \mathrm{kg}$, the soil volume was $1.32 \mathrm{~g} / \mathrm{cm} 3$, the specific gravity was $2.74 \mathrm{~g} /$ $\mathrm{cm} 3$, and the porosity was $51.8 \%$, while the plowing of the soil in the conditions of ancient irrigated grazing fallow soils $(0-30 \mathrm{~cm})$ in the layer contains humus $1.14 \%$, total nitrogen $2.43 \%$, phosphorus $2.31 \%$, potassium $2.32 \%$, their mobile forms are 13.9, respectively; 22.5; At $212 \mathrm{mg}$ / $\mathrm{kg}$, the soil volume was $1.34 \mathrm{~g} / \mathrm{cm} 3$, the specific gravity was $2.76 \mathrm{~g} / \mathrm{cm} 3$, and the porosity was $52.4 \%$.
The results of the research show that the number of plants per $1 \mathrm{~m} 2$ of each variety, the number of productive stems, accumulation and plant height were as follows based on the biological characteristics of the varieties, ie the number of plants per $1 \mathrm{~m} 2$ of Selyanka variety of winter wheat grown in light gray soils. 308 grains, the number of productive stalks was 385 grains, the accumulation was 0.8 grains and the plant height was 82 $\mathrm{cm}$, while the Turkestan variety of winter wheat was 383 in accordance with the above; 479; 1.1 and $84 \mathrm{~cm}$, Krasnadarskaya-99 navida $305 ; 381 ; 1.7$ and $80 \mathrm{~cm}$ and 306 in the Jayhun variety of winter wheat; 386; 1.2 and 92 $\mathrm{cm}$. When studying the same varieties in the conditions of barren soils, the Selyanka variety of winter wheat had 309 plants per $1 \mathrm{~m} 2$, the number of productive stems was 387 , the accumulation was 0.9 and the plant height was $85 \mathrm{~cm}$, while the Turkestan variety was $385 ; 473 ; 1.2$ and $89 \mathrm{~cm}$, 308 in Krasnadarskaya-99 variety; $379 ; 1.5$ and $86 \mathrm{~cm}$ and 307 in Jayhun variety; 383; 1.2 and $87 \mathrm{~cm}$ were observed.

We know that each variety can be distinguished according to its biological characteristics. Depending on the results of phenological analysis, it is possible to determine the duration of the process of growth and maturation of the plant. According to the results of the observation, Selyanka variety of winter wheat, grown in light gray soils, passed into the milk ripening phase on May 12, wax ripening phase on May 20 and full ripening phase on June 6, Turkestan variety on May 13, May 21, June 7, respectively. ; Krasnadarskaya-99 variety was matured on May 15, May 23, June 9 and Jayhun variety on May 17, May 25, June 11, or Turkestan variety vegetation period was 1 day, Krasnadarskaya-99 variety was 3 days late and Jayhun variety was 5 days late compared to Selekta variety. . In the study of winter wheat varieties under similar tillage conditions, Selyanka variety entered the milk ripening phase on May 13, wax ripening phase on May 21 and full ripening phase on June 7, Turkestan variety on May 14, May 22, June 8, respectively; Krasnadarskaya-99 variety matured on May 16, May 24, June 10 and Jayhun variety on May 18, May 26, June 12, or Turkestan variety has a 1-day late ripening period, Krasnadarskaya-99 variety has a ripening period of 3 days and Jayhun variety has a 5-day late ripening period. , Table 1. 
Table-1

Influence of winter wheat varieties on phenological observations

\begin{tabular}{|c|c|c|c|c|c|c|c|c|c|}
\hline \multirow[b]{2}{*}{ № } & \multirow[b]{2}{*}{ Varieties } & \multirow[b]{2}{*}{ 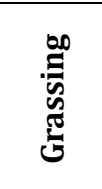 } & \multirow[b]{2}{*}{ 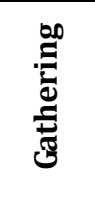 } & \multirow[b]{2}{*}{ 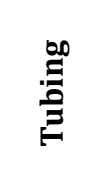 } & \multirow[b]{2}{*}{ 泀 } & \multicolumn{3}{|c|}{ Ripening period } & \multirow[b]{2}{*}{$\begin{array}{c}\text { Vegetation } \\
\text { period }\end{array}$} \\
\hline & & & & & & 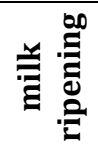 & 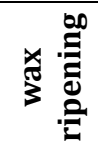 & 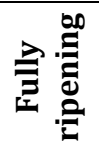 & \\
\hline \multicolumn{10}{|c|}{ In light gray soil conditions } \\
\hline 1 & Selyanka & 20.11 & 7.01 & 10.03 & 20.04 & 12.05 & 20.05 & 6.06 & 185 \\
\hline 2 & Jayxun & 23.11 & 12.01 & 15.03 & 25.04 & 17.05 & 25.05 & 11.06 & 190 \\
\hline 3 & Krasnadarskaya-99 & 23.11 & 10.01 & 13.03 & 23.04 & 15.05 & 23.05 & 9.06 & 188 \\
\hline 4 & Turkiston & 21.11 & 8.01 & 11.03 & 21.04 & 13.05 & 21.05 & 7.06 & 186 \\
\hline \multicolumn{10}{|c|}{ In the conditions of barren soils } \\
\hline 1 & Selyanka & 21.11 & 8.01 & 11.03 & 21.04 & 13.05 & 21.05 & 7.06 & 186 \\
\hline 2 & Jayxun & 23.11 & 13.01 & 16.03 & 26.04 & 18.05 & 26.05 & 12.06 & 191 \\
\hline 3 & Krasnadarskaya-99 & 23.11 & 11.01 & 14.03 & 24.04 & 16.05 & 24.05 & 10.06 & 189 \\
\hline 4 & Turkiston & 22.11 & 9.01 & 12.03 & 22.04 & 14.05 & 22.05 & 8.06 & 187 \\
\hline
\end{tabular}

In the research methodology, using a four-term harvest, the 1 st harvest is carried out when the plant stem is $75 \%$ yellow (approximately 10 days before full ripening); 2nd harvest when the plant reaches the full ripening phase; 3 days after the full ripening phase of harvest 3; The 4th harvest was carried out 20 days after the full ripening phase, Table 2.

According to the results, a separate harvest period was determined for each variety. In the conditions of ancient irrigated grazing light gray soils, depending on the harvest time, the highest yield was 61 ts / ha from Krasnadarskaya-99 variety when the 2 nd crop reached full maturity, the lowest yield was 52.1 ts / ha from Jayhun variety, 4th crop. when carried out after 20 days from the full ripening phase in all varieties ranged from 32.8 ts / ha to 42.4 ts / ha. It was observed that the highest yields were obtained from the Selyanka variety at $53.3 \mathrm{t} / \mathrm{ha}$ and the lowest yield at the Krasnadarskaya-99 variety at $50.7 \mathrm{t} /$ ha when the same varieties were grown in loamy soils.

Table -2

Impact of harvest times on grain yield of winter wheat, ts / ha

\begin{tabular}{|c|c|c|c|c|c|c|c|c|}
\hline \multirow[b]{2}{*}{ № } & \multirow[b]{2}{*}{ Sorts } & \multirow[b]{2}{*}{ 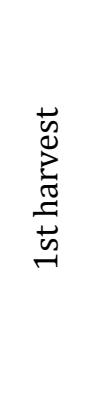 } & \multirow[b]{2}{*}{ 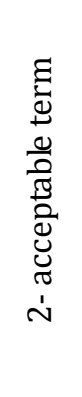 } & \multirow[b]{2}{*}{ 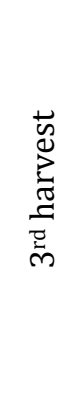 } & \multirow[b]{2}{*}{ 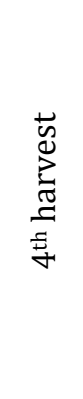 } & \multicolumn{3}{|c|}{ Назоратга нисбатан фарқ } \\
\hline & & & & & & 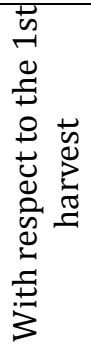 & 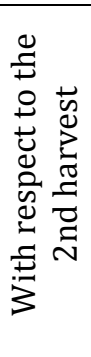 & 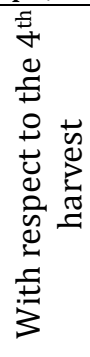 \\
\hline \multicolumn{9}{|c|}{ In light gray soil conditions } \\
\hline 1 & Selyanka & 59,5 & 60,0 & 54,9 & 36,1 & $-4,6$ & 5,1 & $-18,8$ \\
\hline 2 & Jayxun & 49,1 & 52,1 & 48,0 & 38,7 & $-1,1$ & 4,1 & $-9,3$ \\
\hline 3 & Krasnadarskaya-99 & 51,9 & 61,0 & 55,3 & 42,4 & 3,4 & 5,7 & $-12,9$ \\
\hline 4 & Turkiston & 53,5 & 55,0 & 48,8 & 32,8 & $-4,7$ & 6,1 & $-16,0$ \\
\hline \multicolumn{9}{|c|}{ In the conditions of barren soils } \\
\hline 1 & Selyanka & 50,6 & 53,3 & 52,1 & 50,0 & 1,6 & 1,2 & $-2,1$ \\
\hline 2 & Jayxun & 49,7 & 51,5 & 48,8 & 46,9 & $-0,9$ & 2,7 & $-1,9$ \\
\hline 3 & Krasnadarskaya-99 & 46,1 & 50,7 & 48,3 & 45,5 & 2,1 & 2,4 & $-2,7$ \\
\hline 4 & Turkiston & 51,0 & 51,5 & 48,1 & 46,8 & $-2,9$ & 3,4 & $-1,3$ \\
\hline
\end{tabular}


Samples from winter wheat varieties were first taken from freshly harvested wheat grains and placed in a thermostat at $200 \mathrm{C}$ to determine germination, and 100 grains from each variety were placed in parallel in 4 turns, Table 3.

While the moisture content of the grain harvested from the Selyanka variety of winter wheat was $12.5 \%$ when it was originally brought from the field, the moisture content of the grain also changed during storage due to air temperature and relative humidity. The germination energy was initially 2\%, 79\% after 1 month, $99 \%$ after 3 months, the yield varied from $12.2 \%$ to $99 \%$, and the initial moisture content of the grain in the Jayhun variety of winter wheat was $11.4 \%$. In this case, the grain harvested from the field was put into production. In this case, the germination energy is $3 \%$, germination $18 \%$, after 1 month, the moisture content of the grain is $13.4 \%$, germination energy is $81 \%$, germination is $87 \%$, after 3 months, the moisture content of the grain is $12.5 \%$, The germination energy was $98 \%$, the germination rate was $98 \%$, the yield of winter wheat Krasnadarskaya-99 was $12 \%$, the germination energy was $2.2 \%$, the germination rate was $24 \%$, and the germination rate was $12.2 \%$ after 1 month. $\%$, germination energy $88 \%$, germination $90 \%$, initial moisture content of grain $12.5 \%$ when sown after 3 months, it germination energy $98 \%$, germination $98 \%$, winter wheat Turkestan wheat initial moisture content $12.4 \%$, germination energy $2 \%$, germination $16 \%$, after 1 month the initial moisture content of the grain $13.3 \%$, germination energy $67 \%$, germination $78 \%$, Initial humidity after 3 months was $14 \%$, germination energy was $99 \%$, germination was $99 \%$.

Table-3

Dependence of winter wheat grain germination on the physiological dormancy period of grain

\begin{tabular}{|c|c|c|c|c|c|c|c|c|c|c|c|c|}
\hline \multirow[b]{2}{*}{ Tracking time } & \multicolumn{3}{|c|}{ Selyanka } & \multicolumn{3}{|c|}{ Jayxun } & \multicolumn{3}{|c|}{ Krasnadarskaya-99 } & \multicolumn{3}{|c|}{ Turkiston } \\
\hline & 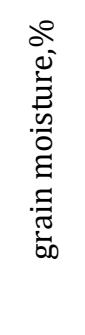 & 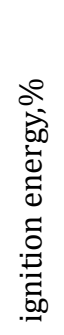 & 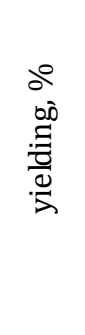 & 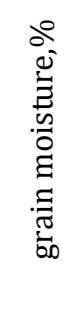 & 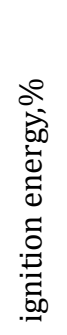 & 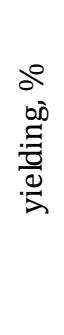 & 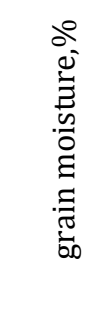 & 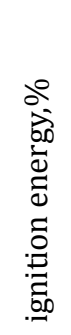 & $\begin{array}{l}d e \\
.00 \\
: \frac{0}{0} \\
\frac{0}{d}\end{array}$ & 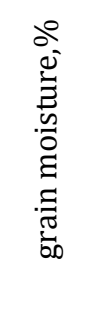 & 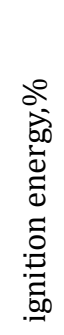 & 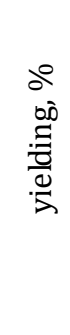 \\
\hline $\begin{array}{l}\text { After the } \\
\text { harvest }\end{array}$ & 12,5 & 2 & 12,2 & 11,4 & 3 & 18 & 12 & 2,2 & 24 & 12,4 & 2 & 16 \\
\hline $\begin{array}{l}\text { After } 1 \text { month of } \\
\text { storage }\end{array}$ & 13,6 & 79 & 80 & 13,4 & 81 & 87 & 12,2 & 88 & 90 & 13,5 & 67 & 78 \\
\hline $\begin{array}{l}\text { After } 3 \text { month of } \\
\text { storage }\end{array}$ & 14 & 99 & 99 & 13,8 & 98 & 98 & 12,5 & 98 & 98 & 14 & 99 & 100 \\
\hline
\end{tabular}

\section{CONCLUSION}

Selyanka variety of winter wheat, grown in Kashkadarya region on irrigated, grazing light gray soils, passed to the milk ripening phase on May 12, wax ripening phase on May 20 and full ripening phase on June 6 , Turkestan variety on May 13, May 21, 7, respectively. June; Krasnadarskaya-99 variety was matured on May 15, May 23, June 9 and Jayhun variety on May 17, May 25, June 11, or Turkestan variety vegetation period was 1 day, Krasnadarskaya-99 variety was 3 days late and Jayhun variety was 5 days late compared to Selekta variety. .

2. In the study of winter wheat varieties in the southern soils of the southern region, Selyanka variety entered the milk ripening phase on May 13, wax ripening phase on May 21 and full ripening phase on June 7,
Turkestan variety on May 14, May 22, June 8, respectively; Krasnadarskaya-99 variety was matured on May 16, May 24, June 10 and Jayhun variety on May 18, May 26, June 12, or Turkestan variety with Selekta variety had a 1-day growing season, Krasnadarskaya-99 variety with 3 days and Jayhun variety with 5 days late ripening. ;

3. Turkestan and Krasnadarskaya-99 varieties, Selyanka and Jayhun varieties of winter wheat grown in ancient irrigated soils in the southern region of the country in the conditions of light gray soils grazing in order to obtain high and high-quality winter wheat. Harvesting is recommended when it reaches the full ripening phase by June 12th.

Acknowledments: We are grateful to the head of the Kashkadarya Research Institute of Selection and Seed 
Production of Cereals for carrying out this research in the framework of the priority direction of the development of science and technology of the Republic V. "Agriculture, Biotechnology, Ecology and Environmental Protection".

\section{REFERENCES}

1. Decree of the President of the Republic of Uzbekistan dated July 17, 2019 No PF-5742 "On measures for the efficient use of land and water resources in agriculture", the newspaper O'zbekiston ovozi, 2019, No 1213.

2. Resolution of the Cabinet of Ministers of the Republic of Uzbekistan No. 74 of February 2, 2018 "On urgent measures to ensure the guaranteed supply of water to crops in the 2018 season and prevent the negative consequences of water scarcity", O'zbekiston ovozi newspaper, 2018, 36the end.

3. Resolution of the President of the Republic of Uzbekistan No. PF-4947 of February 7, 2017 "On the Action Strategy for the five priority areas of development of the Republic of Uzbekistan in 2017 2021", O'zbekiston ovozi, 2017, No. 38.

4. Norkulov U., Sheraliev H., Berdiboev E. One of the important factors of grain cultivation technology is the irrigation regime. "Journal of Agriculture of Uzbekistan". Tashkent, 2004. № 10. B 18.

5. Khalikov B.M, Abdurahmonov S.O, Tungushova D., Boltaev S.M, Abdullaev I. Recommendations to farms of Tashkent and Surkhandarya regions on the use of resource-saving technologies in the cultivation of winter wheat // Recommendation. Tashkent, 2018, -P.32.

6. Abduraxmonov S.O., Abdullaev I.I. Non-traditional fertilizers - both grain and straw // Agro ilm. Scientific application of the Journal of Agriculture of Uzbekistan, Tashkent, 2018, №1 (51) pages 2021 .

7. Kodirova Sh.I. Influence of moisture-accumulating irrigation and fertilizer norms on the growth and development of winter wheat, abstract written for the degree of Doctor of Philosophy in Agricultural Sciences, Tashkent-2018, p.48.

8. Gandjaeva L.A. Author's abstract for the degree of Doctor of Philosophy in Agricultural Sciences, Tashkent-2018, p. 48, to assess the impact of sowing wheat varieties, fertilizer standards and irrigation regimes on productivity.

9. Hasanova R.Z. The effect of urea feeding on soft wheat leaves on grain yield and quality, abstract for the degree of Doctor of Philosophy in Agricultural Sciences, Tashkent-2018, p.48.

10. Oripov R., Sulaymonov I. Technology of storage and processing of agricultural products, Tashkent 2004, - P.75-79.

11. Methods of agrochemical, agrophysical and microbiological studies in irrigated lands. Tashkent. USSRCRI, 1963. P. 439.

12. Methods of agro physical studies. Tashkent. 1973., P.173.
13. Methods of agro chemical analysis of soil and plants. Tashkent 1977., P.248.

14. Mehtods of conducting field experiments. Tashkent, 2007. P.148.

15. Kenjabaev Sh., Hans Georg Frede, Begmatov I., Isaev S., Matyakubov B. -Determination of actual crop evapotranspiration (etc) and dual crop coefficients $(k c)$ for cotton, wheat and maize in Fergana Valley: Integration of the fao-56 approach and budget. Journal of Critical Reviews ISSN2394-5125 Vol 7, Issue 5, 2020, p. 340-349.

16. Matyakubov B., Isabaev K., Yulchiyev D., Azizov Sh. Recommendations for improving the reliability of hydraulic structures in the on-farm network. Journal of Critical Reviews ISSN-2394-5125 Vol 7, Issue 5, 2020, p. 376-379.

17. Matyakubov B., Begmatov I., Mamataliev A., Botirov Sh, Khayitova M. Condition of irrigation and drainage systems in the Khorezm region and recommendations for their improvement. Journal of Critical Reviews ISSN- 2394-5125 Vol 7, Issue 5, 2020, p. 417-421.

18. Khamidov M., Matyakubov B., Isabaev K. Substantiation of cotton irrigation regime on meadow-alluvial soils of the Khorezm oasis. Journal of Critical Reviews ISSN-2394-5125 Vol 7, Issue 4, 2020, p. 347-353.

19. Mohan Reddy, Jumaboev K., Matyakubov B., Eshmuratov D. Evaluation of furrow irrigation practices in Fergana Valley of Uzbekistan. Agricultural water management. 2013; p. 133-144.

20. Sommer, R., Glazirina, M., Yuldashev, T., Otarov, A., Ibraeva, M., Martynova, L., Bekenov, M., Kholov, B., Ibragimov, N., Kobilov, R., Karaev, S., Sultonov, M., Khasanova, F., Esanbekov, M., Mavlyanov, D., Isaev S., Abdurahimov, S., Ikramov, R., Shezdyukova, L., De Pauw, E.: Impact of climate change on wheat productivity in Central Asia. Agronomy Journal, $78-99$ (2013). DOI: doi.org/10.1016/j.agee.2013.06.011. 